УДК 347.471:329 (477)

https://doi.org/10.34142/24130060.2019.17.1.17

\title{
ГРОМАДСЬКІ ОБ'ЄДНАННЯ ЯК ІНСТИТУЦІОНАЛІЗОВАНА ФОРМА СУСПІЛЬНИХ РУХІВ: УКРАЇНСЬКИЙ КОНТЕКСТ
}

\author{
Т.П. Савельсва, І.І. Пелішенко
}

Харківський національний педагогічний університет імені Г.С.Сковороди

У статті здійснено спробу окреслення особливостей суспільних рухів через їх організаційну (інституціоналізовану) форму - громадські об'єднання.

Визначено доиільність специффіки такого підходу, яка полягає в першу чергу у наявності певних співвідношень між даними об'єднаннями. Для реалізації мети дослідження в першу чергу пропонується звернути увагу на дві основні характеристики, щуо стосуються діяльності громадських організачій - їх кількість та рівень залученості громадян.

Ключові слова: суспільні рухи, громадські об'єднання, громадські організації, колективна дія.

\section{ОБЩЕСТВЕННЫЕ ОБЪЕДИНЕНИЯ КАК \\ ИНСТИТУЦИОНАЛИЗИРОВАННАЯ ФОРМА ОБЩЕСТВЕННЫХ ДВИЖЕНИЙ: УКРАИНСКИЙ КОНТЕКСТ}

\section{Т.П. Савельева, И.И. Пелишенко}

В статье предпринята попытка определения особенностей общественных движений через их организационную (институциионализированную) форму общественные объединения.

Определена иелесообразность специфики такого подхода, которая заключается в первую очередь в наличии определенных соотночений между данными объединениями. Для реализации цели исследования в первую очередь предлагается обратить внимание на две основные характеристики, касающиеся деятельности общественных организачий их количество и уровень вовлеченности граждан.

Ключевые слова: общественные движения, общественные объединения, общественные организации, коллективное действие.

\section{PUBLIC ASSOCIATIONS AS AN INSTITUTIONALIZED FORM OF SOCIAL MOVEMENTS: UKRAINIAN CONTEXT}

\section{T. Savelieva, I. Pelishenko}

The article attempts to determine the characteristics of social movements through their organizational (institutionalized) form - public associations.

In the conditions of the emergence of a «new» type of society, the network, it is shown that it is public movements are becoming new institutions of public interest representation through to the crisis of traditional mechanisms of representation of interests. In connection with the complexity of the analysis of social movements, which is associated with the 
main characteristics of the latter: dynamic nature, absence of a clear organizational structure, the availability of various forms (protests, flashmobs, revolutions, various actions), diverse scale of manifestation, mostly not a sufficiently long existence - it is proposed to consider the institutionalized form of social movements - public associations (organizations).

It was determined the expediency of the specifics of such an approach, which consists primarily in the presence of definite correlations between social movements and public organizations.

To achieve the goal of the study, it is first proposed to pay attention to two main characteristics relating to the activities of public organizations - their number and level of citizen involvement.

Analysis of the results of sociological research and statistical data showed some discrepancies between official data and personal opinion of citizens regarding their participation in public organizations, which is most likely related to the specifics of the activities of these organizations in Ukrainian society.

As a result, we came to the conclusion that today, social movements in Ukrainian society act primarily through a network of public organizations (women's, environmental movement, etc.) Also, social movements appear as a certain form of interaction, which is associated with crisis periods as a whole in society and in its individual spheres. It is noted that the participation of citizens in public associations in Ukraine today remains more formalized.

Keywords: social movements, public associations , public organization, collective action.

Постановка проблеми. Першочергові зміни, що супроводжують українське суспільство з моменту отримання незалежності, спрямовані на демократизацію усіх сфер суспільно-політичного життя. Впровадження демократії передбачає наявність громадянського суспільства, яке у свою чергу пов'язано із функціонуванням певного комплексу незалежних від держави організацій та суспільно активних громадян, що у своїй сукупності беруть на себе функцію суспільного контролю над державним механізмом. Зв’язок «громадянських суспільств» із визнанням різноманітності групових інтересів у поєднанні із захистом індивідуальних прав, та відповідне об’єднання громадян у різноманітні асоціації організують різноманіття інтересів поза державою. Групи інтересів як осередки «взаємодії, спілкування й солідарності, провадження власне громадського (публічного) життя та спільного (колективного) вирішення проблем» (Бех ред., 2011, с. 2930) пов’язані із асоціативними об’єднаннями, що постають виразником певних громадських інтересів та прагнень, і чільне місце серед них посідають суспільні рухи.

В умовах сучасного суспільства важливість даного актору суспільнополітичного простору є беззаперечною і доведеною наявними результатами 
ïx діяльності в багатьох країнах (в тому числі і в Україні). В той же час дослідження суспільних рухів потребує розробки підходів, інструментарію, які надали б можливість в більшій мірі коректно, чітко відобразити реальний стан речей, особливості їх функціонування в сучасних умовах.

Аналіз актуальних досліджень. Основна увага дослідників, що впродовж декількох століть вивчали проблемне поле суспільних рухів, в першу чергу була прикута до розробки категоріально-понятійного апарату в межах теорії суспільних рухів, появу якої можна датувати серединою XX століття. Серед найбільш відомих західних вчених, що здійснили чималий вклад до розвитку даної теорії можна назвати: Г. Блумера, Ю. Габермаса, Т. Гарра, М. Зальда, Р. Інгельхарта, М. Кастельса, С. Ліпсета, Дж. Мак-Карті, А. Мелуччі, Е. Обершол, Ч. Тіллі, А. Турена та інших.

Вітчизняні дослідники, користуючись вже набутими доробками в межах теорії суспільних рухів запропонували чимало нових ідей, які пов'язані із особливостями сучасного суспільства. Одним із таких напрацювань є розгляд суспільних рухів через громадські об'єднання, однією 3 форм яких є громадські організації (О. Стегній, I. Тімкін, Т. Черкашина, О. Яницький та інші).

Метою статті $\epsilon$ спроба розглянути особливості функціонування громадських об'єднань у якості інституціоналізованої форми суспільних рухів у контексті розвитку сучасного українського суспільства.

Виклад основного матеріалу. Розглядаючи суспільні рухи у якості колективної спроби здійснення спільної діяльності людей 3 метою досягнення їх спільних інтересів (Гидденс, 1999, с. 585), приймається до уваги важливість даного актору відповідно як для презентації, задоволення та захисту різноманітних групових інтересів (відповідно до професійної приналежності, вікових особливостей, індивідуальних нахилів тощо), їх артикуляції, так і для реалізації наступних функцій: політична соціалізація особистості; залучення громадян до процесу прийняття політичних рішень (участь в управлінні); вирішення задач, проблем, актуальність яких 
пов'язується не тільки із конкретною групою, але й загалом 3 політичною системою суспільства, в яку дані групи включені.

У зв’язку із появою суспільства «нової якості» (мережевого), саме суспільні рухи стають новими інститутами представництва суспільних інтересів через кризу традиційних механізмів представництва інтересів та їх неможливістю забезпечити широку участь (безпосередню або опосередковану) у процесі прийняття політичних рішень (Павлова, 2008, с. 116-117). Серед таких, наприклад, партії - на сьогоднішній день не виконують повною мірою свою функцію щодо посередника між громадянами і владою. Відповідно, ми спостерігаємо низький рівень довіри до даного інституту - за даними опитування Центру Разумкова, яке проводилось у червні 2018 р., рівень недовіри до партій склав 80\%, при цьому рівень довіри загалом до громадських організацій склав 43,4\%, i, окремо, до волонтерських організацій - 65,2\% (Центр Разумкова, 2018).

Оскільки суспільні рухи являють собою досить складне утворення, що характеризується через колективну дію, яка у свою чергу має специфічну структуру (за Ч. Тіллі - це наявність організації групи чи груп, що є учасниками протестних акцій; мобілізація; спільні інтереси учасників колективної дії; сприятливі обставини) (Савельєва, 2017, с.172), аналіз рухів ускладнюється наступними моментами: вони мають динамічний характер, не мають чіткої організаційної структури через відсутність інституційних характеристик, виявляють свою діяльність у багатогранних формах (протести, флешмоби, революції, акції на підтримку тощо), діють на різноманітних рівнях та, відповідно, мають різний масштаб прояву, неоднорідні за складом, найчастіше існують не досить тривалий час.

У зв’язку із цим, при аналізі суспільних рухів доречним є розгляд їх інституціоналізованої форми - різноманітних громадських об’єднань, зокрема, громадських організацій. Доцільність даної пропозиції обумовлена певним співвідношенням між даними об’єднаннями: по-перше, громадські організації як інституціоналізована форма суспільна рухів у сучасних 
соціально-політичних реаліях домінують на відміну від останніх, виконуючи при цьому подібні функції; по-друге, сутність суспільного руху подекуди пов'язується із діяльністю громадських організацій (в даному випадку рух постає сукупністю видів діяльності різноманітних громадських організацій); по-третє, науковцями зазначається, що або ж організації виникають через певні колективні дії, що мають масовий характер, або ж, навпаки, організації існують до масових дій і самі безпосередньо здійснюють вплив на виникнення та розповсюдження колективних дій (рухів) (Костюшев, 2009); та, по-четверте, необхідно звернути увагу на спільні риси, що об’єднують суспільні рухи та організації - мережа взаємодій, що спрямована на громадську самоорганізацію, представлення різноспрямованих інтересів, спрямованість на досягнення соціально значущих цілей, вплив на прийняття політичних рішень. Загалом, при розгляді громадських організацій у відповідності до моделі розвитку демократичного суспільства, приймається до уваги той факт, що їх постійна взаємодія утворює своєрідний консолідований громадський рух, який має спроможність ефективної взаємодії з органами державної влади (Всеукраїнська громадська організація «Асоціація сприяння самоорганізації населення», 2008, с. 18).

Звертаючи увагу на зовнішні ознаки поведінки, С. Хантінгтон (2004, с. 105) наголошує на різниці між політично розвинутим та нерозвинутим суспільством, що виявляється в першу чергу величиною та ефективністю наявних в ньому організацій. Отже, аналізуючи діяльність громадських організацій, перше, на що ми звертаємо увагу - їх кількість та рівень залученості населення до їх діяльності.

Відповідно до даних, зафіксованих Державною службою статистики України, кількість громадських організацій за останні роки збільшується (що $€$ загальносвітовою тенденцією), при цьому зменшується кількість членів даних організацій. Відповідно до обліку керівних органів громадських організацій, без урахування тимчасово окупованих територій, за даними служби, у 2014 році їх нараховувалося 21417 одиниць при кількості членів - 
27008586 осіб. Останні дані, що представлені службою (за 2017 рік) фіксують 25988 одиниць громадських організацій при 19925386 осіб, що є їх членами (Кармазіна, 2013, с. 70-71). Ураховуючи наявну кількість населення (без урахування тимчасово окупованих територій), вираховується, що близько 47\% населення України перебуває у складі громадських організацій.

За таких офіційних даних виникає певне протиріччя при зверненні до даних дослідження, проведеного Фондом «Демократичні ініціативи» імені Ілька Кучеріва спільно з соціологічною службою Центру Разумкова 319 по 25 травня 2018 року в усіх регіонах України за винятком Криму та окупованих територій Донецької та Луганської областей. Так, близько 87\% громадян зазначають про свою незалученість до жодного 3 громадських об'єднань і лише 5,2\% визнають себе членами громадських організацій. Як зазначають дослідники, у порівнянні з аналогічними результатами у 2013 році, відповідні дані практично не зазнали змін (Фонд Демократичні ініціативи імені Ілька Кучеріва, 2018а)

Такий дисбаланс між офіційною статистикою та наявною особистою думкою громадян може свідчити про:

- формальність як громадських організацій (існування лише «на папері» для отримання певних коштів чи інших ресурсів, відсутність формальної процедури закриття організації при припиненні активної діяльності тощо), так i членства у них («паперове» членство без відома громадян, «автоматичне» колективне членство тощо), відсутність будь-якої активності даних об'єднань;

- діяльність громадських організацій у форматі аналітичних центрів, що не передбачає в них членства;

- наявність «псевдогромадських» організацій, які, маючи різні назви та відповідно одних й тих самих членів, насправді являють собою одну структуру (Кармазіна, 2013), або ж $є$ так званими «кишеньковими», що замість захисту інтересів громадян зорієнтовані на діяльність у підтримку певної політсили, є певним інструментом для досягнення власних цілей. 
Висновок, який ми можемо зробити i який підтверджується аналітиками - зростання кількості організацій не обов’язково пов’язано із зростанням громадянської участі i, відповідно, збільшенням кількості суспільних рухів.

Досить висока довіра населення до громадських організацій, про рівень якої зазначено вище та неучасть громадян у діяльності цих організацій можна пояснити наступним.

За останні роки у зв’язку із розвитком волонтерського руху, розвитком громадської самоорганізації, яка втілилися у «Революції Гідності» можна було б припустити думку про злам патерналістського менталітету, який залишався домінуючим з радянських часів, що стало рушійною силою для громадян до активного залучення у діях щодо здійснення суспільнополітичних змін. Про даний злам певною мірою свідчать дослідження стосовно особливостей цінностей громадян України - науковці Інституту соціології НАН України, що проводять відповідні дослідження, зазначають про зростання так званих цінностей самореалізації та політикогромадянських цінностей, i це насамперед пов'язується iз адаптацією індивідів до нових умов соціально-політичних реалій. При цьому постматеріалістичні цінності, за даними дослідників, переважають здебільшого у молоді, яка зростала вже у незалежній Україні (Ручка, 2016).

Але, не дивлячись на дані факти, дослідження Фонду «Демократичні ініціативи» імені Ілька Кучеріва спільно з соціологічною службою Центру Разумкова, проведене з 19 по 25 травня 2018 року, звертає увагу не тільки на низькі показники щодо участі у діяльності громадських організацій, але й на низьку громадську активність, про що вказує низький відсоток залученості до громадської діяльності - 7\% населення (8\% у 2013 році) (Фонд Демократичні ініціативи імені Ілька Кучеріва, 2018а). Населення все ще орієнтоване не на власні дії щодо змін (відсутність позиції щодо можливості вкладу в загальний розвиток однією особою), а на державу чи уявних «інших». 
Відповідна пасивність а також відсутність власної відповідальності за те, що відбувається у суспільстві та уявлення стосовно можливості масштабних змін силами народу, але без власної участі виявляються у наступних даних: понад 50\% респондентів вважають, що за останні два роки (дані станом на кінець 2015 р.) вони помітили зростання готовності в суспільстві до об’єднання в громадські організації та ініціативи, при цьому лише 17,7\% відзначили аналогічні зміни у собі; відповідно 40\% опитаних звертають увагу на сконцентрованість населення на громадській діяльності у суспільстві і лише 13\% відзначають иї наявність у себе (Фонд Демократичні ініціативи імені Ілька Кучеріва, 2018b).

На думку В. Степаненко (2015, с. 270), великий відсоток «неучасті» громадян можна пояснити байдужістю, пасивністю людей до суспільного життя та зневірою у можливості захисту своїх прав та інтересів.

Погляд власне громадян на свою неучасть у діяльності громадських організацій підтверджує думку науковця i пов'язаний iз наступними причинами: брак часу на безоплатну роботу $(28 \%)$, переконання у неможливості щось змінити своєю участю (23\%), відсутність інтересу до такої діяльності (22\%), незнання, яким чином це можна зробити (16\%) (Фонд Демократичні ініціативи імені Ілька Кучеріва, 2018а).

В той же час, переважна більшість громадян (60\%) погоджується, що громадські організації необхідні в їх населених пунктах, 42\% респондентів навіть мають бажання спрямувати частину своїх податків у їх підтримку (Фонд Демократичні ініціативи імені Ілька Кучеріва, 2018а). Тобто, дійсно, зневіра людей у власні сили, відсутність матеріальних ресурсів, часу (вплив української специфіки соціально-економічного становища), практичного та теоретичного досвіду, пов'язаного із даними об’єднаннями, вимальовують той стан громадських організацій та суспільних рухів, який в більшій мірі можна назвати активною імітацією громадської діяльності, і лише в періоди суспільно-політичних криз спостерігається підйом протестної активності, яка веде до протестних рухів, акцій що об’єднують окремих громадян та 
різноманітні громадські об’єднання і дають поштовх для створення нових об’єднань («Революція на граніті», «Україна без Кучми», «Помаранчева революція», «Революція Гідності» тощо).

Висновки i перспективи подальших досліджень. Виходячи iз сутності суспільних рухів, які в теоретичному плані досить складно вивчати через їх певну специфіку, 3 урахуванням сучасних реалій розвитку українського суспільства, та зважаючи в тому числі на загальносвітові тенденції щодо зростання недержавних організацій на різних рівнях суспільної організації (від місцевого до світового), дія яких постає у формі мереж i тому вже являє собою суспільний рух, розгляд їх інституціоналізованої форми - громадських об’єднань, є доцільним та прийнятним.

Аналіз одного 3 різновидів громадських об’єднань - громадських організацій в контексті розвитку сучасного українського суспільства показав, що для українського суспільства, яке рухається в напрямку демократизації, участь населення у громадських об’єднаннях на сьогодні залишається, на жаль формалізованою - статистичні показники щодо членства у громадських організаціях є досить умовним показником активності населення.

Саме тому суспільні рухи, що існують в українському суспільстві і діють через мережу громадських організацій, по суті є «новими», а для нас діють як традиційні - жіночий рух, екологічний рух тощо не можна назвати активно діючими. Якщо дотримуватися визначення А. Колодій (2001), де суспільні рухи постають у формі певної взаємодії, яка взаємопов’язана із кризовими періодами або ж в суспільстві загалом, або ж в окремих його сферах життєдіяльності, в такому разі, наприклад, зі сплесками протестної активності, ми спостерігаємо протестні рухи, або ж рухи, які викликані нагальними суспільно-політичними проблемами (військові дії на Сході України - волонтерський рух тощо).

Ураховуючи наявний стан речей щодо стану та діяльності громадських організацій (їх велика кількість та низька громадянська активність і участь в 
даних об’єднаннях) можна припустити, що функції, які вони повинні виконувати, реалізуються не повною мірою. Важливість колективної дії суспільних рухів та громадських організацій для розвитку українського суспільства визначає за необхідне активізацію самоорганізації громадян, що в свою чергу передбачає зміну системи цінностей та моделей поведінки, для чого необхідне не одне десятиліття, при цьому потрібна неабияка «підтримка» громадян з боку соціально-політичної системи.

\section{ЛІТЕРАТУРА}

1. Бех, В.П. ред., 2011. Громадські організації у дискурсі демократизаиії суспільства: монографія. Київ: НПУ імені М. П. Драгоманова.

2. Всеукраїнська громадська організація «Асоціація сприяння самоорганізації населення», 2008. Моніторинг діяльності органів місцевого самоврядування щзодо створення умов для розвитку громадських організачій та органів самоорганізачії населення. Аналітичний звіт за підсумками виконання проекту "Вплив місиевої влади на розвиток третього сектору”. [online] Одеса: ХОББІТ ПЛЮС. Доступно: http://samoorg.com.ua/wp-content/uploads/2009/07/vplyv-miscevoi-vlady-na-iii-sektor.pdf [Дата звернення 28 січень 2019].

3. Гидденс, Э. 1999. Социология. Москва: Эдиториал УРСС.

4. Кармазіна, М., 2013. Громадські організації: кого вони представляють? Дзеркало тижня, 15 Лист., [online]. Доступно: https://dt.ua/internal/gromadski-organizaciyi-kogovoni-predstavlyayut-_.html [Дата звернення 28 січень 2019].

5. Кармазіна, О.О., 2017. Діяльність громадських організачій в Украӥні у 2017 роиі. Статистичний збірник. [онлайн] Київ. Доступно: http://www.ukrstat.gov.ua/druk/publicat/kat_u/2018/zb/07/zb_go_2017.pdf [Дата звернення 28 січень 2019].

6. Колодій, А., 2001. Історична еволюція громадянського суспільства та уявлень про нього (формування ідеалу). Незалежний культурологічний часопис «ї», [онлайн] 21. Доступно: http://www.ji.lviv.ua/n21 texts/kolodij.htm [Дата звернення 28 січень 2019].

7. Костюшев, В.В., 2009. Социология общественных движений: Учебный курс. [online] Доступно: https://www.hse.ru/data/2011/05/23/1211175910/Соц.общ.движения.doc [Дата звернення 28 січень 2019].

8. Павлова, Т.В., 2008. Социальные движения как фактор трансформации институциональной среды: проблемы теории. Полис, 5, с. 113-124.

9. Ручка, А.О., 2016. Зміни цінностей украӥнців за 25 років. [онлайн] Доступно: http://isoc.com.ua/ua/news/zmini-cinnostey-ukrainciv-25-rokiv [Дата звернення 20 січень 2019].

10. Савельєва, Т.П., 2017. Суспільні рухи в контексті теорії соціальних змін. Сучасне суспільство, 1(13), с. 167-180.

11. Степаненко, В. 2015. Громадянське суспільство: дискурси і практики. К.: Ін-т соціології НАНУ.

12. Фонд Демократичні ініціативи імені Ілька Кучеріва, 2018а. Громадянське суспільство в Украӥні: виклики $i$ завдання. Опитування. [online] Доступно: https://dif.org.ua/article/gromadyanske-suspilstvo-v-ukraini-vikliki-i-zavdannya [Дата звернення 20 січень 2019]. 
13. Фонд Демократичні ініціативи імені Ілька Кучеріва, 2018b. Громадянська nасивність. [online] Доступно: https://dif.org.ua/article/gromadyanska-pasivnist [Дата звернення 20 січень 2019].

14. Хантингтон, С. 2004. Политический порядок в меняющиихя общеествах. Москва: ПрогрессТрадиция.

15. Центр Разумкова, 2018. Довіра громадян Украӥни до суспільних інститутів. Результати сочіологічного дослідження. [online] Доступно: http://razumkov.org.ua/uploads/socio/2018_06_press_release_ua.pdf [Дата звернення 20 січень 2019].

\section{Інформація про авторів}

Савельсва Тетяна Павлівна - аспірантка кафедри політології, соціології і культурології Харківського національного педагогічного університету імені Г.С. Сковороди; e-mail: savelyeva.tp@gmail.com; ORCID: http://orcid.org/0000-0003-3274-6475.

Пелішенко Ірина Іванівна - кандидат філософських наук, доцент, доцент кафедри політології, соціології і культурології Харківського національного педагогічного університету імені Г.С. Сковороди; e-mail: pelishenkoirina@gmail.com. ORCID: http://orcid.org/0000-0002-4735-9016.

Стаття надійшла до редакції: 31.01.2019 p. $\quad$ Прийнята до друку: 15.02.2019 p. 